\title{
FOREWORD BY GERALDEARLY
}

To have grown up in Philadelphia in the I950s and I960s, as I did, was to experience the American city, American life itself, on the cusp of dramatic change. The rise of reformist liberals in Philadelphia's politics in the I950s coupled with a growing black activism in the city in the r96os, particularly under the leadership of local NAACP president Cecil B. Moore, were the manifestation of one sort of change. The arc of the career of legendary cop Frank Rizzo, who went from being the "Cisco Kid" of the streets to police commissioner and eventually, in I97I, to mayor, was change as well, or the change that change produced. Few people who lived in most big American cities at the time could say that they were not cursed with having to live in an interesting time. Ironically, one could hardly sense this change, in many respects, even as one was living through such strange seasons that would disconnect us all from the past while leaving us unable to discern the future.

I can remember distinctly reading passages from the Bible in my elementary school classes and hearing them read before our weekly "Assemblies" and can vividly recall that teachers could and did use corporal punishment to chastise children. When I tell my children this, they think I grew up in a more primitive and even quaint time. Actually, nothing could be further from the truth. Reading the Bible in school probably did me at least this level of good: that I got to read that book at all in a setting that was not related to church, so I could think about it differently while learning to absorb its mighty language. I do not recall corporal punishment with any fondness at all. I thought it brutal and, perhaps oddly, a rather sensational way to discipline a child. I did not think it was terribly effective. Nor did I think that my teachers cared more about me because they were willing to slap me around. But I do not think, on the other hand, that they cared about me any less. (At least, those of us who went to public school thought, we 
don't get knocked around as much as the kids in Catholic school do by the nuns and priests.) I never feared any teacher's threat of physical violence nearly as much as I feared some of my classmates. And since it was common in the world I grew up in for parents to smack their children around, why not the teachers? There was something that was stabilizing and reassuring about the exercise of this type of authority. But change was on the way and by the time I had finished junior high school, Bible reading and corporal punishment were things of the past.

I grew up in South Philadelphia, near the Italian Market on Ninth Street, in the very heart of an ethnic mosaic of working-class Italians (Mario Lanza had grown up two blocks from where I lived), Irish Catholics, Jews, and, of course, African Americans. What I loved about South Philadelphia, indeed about Philadelphia as a whole, was the fact that the city, and especially this particular section of it, was built for pedestrians, made to be walked in. What I did for hours and hours in my youth was simply walk around all parts of South Philadelphia, sometimes alone, sometimes with friends. Had it not been for the terror of street gangs, I would have walked even more in the city than I did. It was one of the few charms that the city held for me as a child, other than riding public transportation. A surprising number of adults in my neighborhood did not own cars; many women particularly, including my mother, did not even know how to drive.

I saw the first housing projects built in the neighborhood (the Southwark Plaza Projects), and even remember that when they first opened many whites lived there. Of course, they did not stay for long, but in the first year or two those projects were the most integrated community I had seen or have seen since. (I thought it would be like that forever, for I could not, in my childhood, understand the differences that defined the races.) A certain balance existed among the various racial and ethnic groups, and while there were eruptions of violence, the mere telling of which made me tremble with loathing and a sense of entrapment, by and large these groups respected each other's space and even managed to get along with each other in ways that were positively inspiring. In the summer day camps, at Nebinger School and at the House of Industry, I remember Italian children and black children playing together our various games of "Dead-Box," "Checkers," or "Uncle Wiggly" or riding on the swings or the maypole or playing volleyball, reading comic books together, eating slices of cold watermelon with sticky fingers, singing camp songs together with nary a word about how we were all different from each other or needed role models from our own group. We quite understood what made us different, but we were mostly 
glad about what made us alike: watching "American Bandstand," which was still being filmed in Philadelphia in the early i 960s (although we black kids thought that the few black kids on the show danced better), "The Lloyd Thaxton Show," "The Adventures of Rocky and Bullwinkle," "Spin and Marty" on "The Mickey Mouse Club," "The Adventures of Zorro" with Guy Williams, all the latest movies with Troy Donahue or Steve Reeves, and "The Beverly Hillbillies," and listening to WIBG (or WIBBAGE) spinning the Top 40 hits with deejays like Hy Lit. (We black kids also listened to the soul stations like WDAS, with Georgie Woods "the Guy with the Goods," and WHAT with Sonny Hopson "the Mighty Burner," and to a white disc jockey named Jerry Blavatt, "The Geeter with the Heater.") And we all read the Daily News, the second-rate tabloid paper, religiously because our parents did. I perfected my early reading skills reading the sports pages of that paper. Everyone read the daily comic strips, especially "Nancy," to get clues for which numbers to play in the illegal lottery. (People read the strips as if they were deciphering the codes of ancient runes.) And there were three passions that both the blacks and the Italians shared in that neighborhood: going to Atlantic City or Wildwood in the summer, playing the numbers, and playing bingo at the neighborhood Catholic churches. Getting flavorful water ices from John's Water Ice on Seventh Street, walking with my sisters to their piano lessons at the Settlement Music School on Queen Street, standing at the corner of Broad and South on New Year's Day to watch the Mummer's Parade, walking along downtown Market Street at Christmastime to all the department storesStrawbridge and Clothier, Lit Brothers, Gimbel's, and Wanamaker's. What a charm and sweetness Philadelphia was. It was a life that now seems long ago and far away. I think the year that I began to sense real change, a disruption in my own sense of innocence, was in 1964.

The whole country changed following the shocking assassination of John F. Kennedy in 1963. Nothing was ever to be the same again. But even before Kennedy's death, change was in the air. Martin Luther King's bloody campaign in Birmingham in 1963 , which so effectively dramatized the civil rights movement, and the visionary "March on Washington," for which Georgie Woods, the deejay, provided bus transportation for anyone who wanted to go, suggested something remarkable, a sea change, in black life, even if life seemed to go on pretty much as it had before. Everything felt different.

The summer of I 964 was even more startling: "freedom summer" in Mississippi, the deaths of Chaney, Schwerner, and Goodman that so riveted 
the nation, the Mississippi Freedom Democratic Party upsetting the Democratic National Convention, Martin Luther King's badly failing campaign in St. Augustine, Florida, and a race riot in Philadelphia that eventually helped to make Frank Rizzo the police commissioner and sent Howard Leary, the police commissioner Rizzo hated, to New York. It was not as big a race riot as what was to come the next summer in Watts or later in the decade in Detroit, but it was bad enough — three million dollars in damage in 1964 dollars, and the North Philadelphia neighborhood where the riot occurred would never recover economically, at least not during the rest of the time I lived in Philadelphia. (I left the city in 1977.) Police brutality was a huge topic in the black community of Philadelphia in those days. The black newspaper, the Tribune, wrote about it all the time, and it seemed that things just exploded on Friday, August 28, when rumors spread through the black community of North Philadelphia that a woman named Odessa Bradford, who was pregnant, had been killed by the police in a traffic stop. It turned out that Mrs. Bradford was stopped by the police, but she was not harmed. The two officers who stopped her in fact wound up going to the hospital when she resisted arrest. Mrs. Bradford was not pregnant, either.

The riot unfolded anyway and no important black leader at the time could stop it, not Raymond Pace Alexander, one of the city's prominent black lawyers and a former city councilman that many wrongly considered an Uncle Tom, not the popular Georgie Woods, who Frank Rizzo grabbed from the stage of the Uptown Theater during one of Woods's rock-and-roll shows on the night of the riot to try to talk people into going home, not the tough ex-marine and militant president of the local chapter of the NAACP, Cecil B. Moore, who was hit in the head with a brick by the rioters. Mass violence tends to lead a life of its own once the momentum gets it going and people take on the aspects of a mindless mob and principled insurrectionists.

It was this 1964 summer that the Philadelphia Phillies, who played in a stadium not far from the site of the riot, were contending for the pennant, after years of mediocrity. It was the year that Richie Allen, their muscular rookie third baseman, would become the team's first black superstar. It is the story of Philadelphia in the summer of 1964, of this particular Philadelphia team, of this particular player, Richie Allen, that William C. Kashatus tells so richly and compellingly in September Swoon. My only surprise is that no one told this story sooner.

Kashatus tells the story of that entire season almost day by day-how a Philadelphia team, an odd mix of veterans and youngsters, unexpectedly 
came from nowhere to nearly win the pennant, only to collapse in the last two weeks of the season and lose ten of its last twelve games, blowing a sixand-a-half game lead. Spiritually, I don't think Philadelphia ever recovered from that loss until the team won the World Series in I980. Kashatus also tells the story of race relations in Philadelphia, how Allen's arrival affected not only the team but the city itself, a city that had worked out over many long decades its way of dealing with blacks only to find that the old way of doing business was coming to an end.

In my growing up, very few black people I knew rooted for the Phillies, most having long memories of how Philadelphia manager Ben Chapman mercilessly taunted Brooklyn Dodger Jackie Robinson with racial insults and invective when Robinson arrived in the Majors. As my mother said to me once, "I'll root for the Phillies when hell freezes over." In i 964, for my mother, hell definitely did not freeze over and she was in fact ecstatic when the team went into its free fall at the end of the season. I suppose I wanted the Phillies to win, but I was not very disappointed when they lost. I almost expected it. But the impact of that season has stayed with me all my life, in a way that no other baseball season has.

Allen himself was a curious man, moody and often incommunicative with the press, but possessed of tremendous power and athletic ability. Most black people felt that Allen was poorly covered by the white press, blamed for the team's collapse, and eventually run out of town, and Kashatus ably tells the story of how the press shaped and misshaped Allen's public persona. September Swoon is a wonderful book and an important one as well, not just for baseball fans, but for readers interested in race and sports, and sports and its impact on urban history. As a former Philadelphian who lived through the days he describes, I am very grateful to him for having written the book.

It is perhaps not a kindness, as a person who grew up in Philadelphia, that I wound up living in St. Louis. First, it was St. Louis that beat Philadelphia for the 1964 pennant and went on to beat the Yankees in the World Series. Second, Dick Allen (he never wanted to be called Richie, he said) was traded to the St. Louis Cardinals in I 969 for outfielder Curt Flood. (Other players were involved in the trade, but Allen and Flood were the principals.) Flood never played a game in Philadelphia, opting instead to sue baseball under the nation's antitrust laws, saying that the sport's reserve clause prevented him from exercising the same right as other American workers, the right to offer his services to whoever might want them. He didn't win the suit, but it did set things in motion that eventually led to free 
agency in I975. At the time of Flood's suit, I thought to myself, "Geez, the guy would rather destroy his career and sue baseball than play in Philadelphia." That thought so depressed me that I stopped following baseball for several years. In recent years, I was not happy when J. D. Drew chose to come to St. Louis instead of signing with Philadelphia; nor was I happy when Scott Rolen came to St. Louis either, after rejecting the Phillies. I have no sentimental feelings for Philadelphia and I don't desire to live there again, but something about what Drew and Rolen did wounded me deeply. I enjoy St. Louis and feel lucky to live in a city with such a competitive baseball team. It nearly goes without saying, as I live in St. Louis, I root for the St. Louis Cardinals, a great franchise, as I have done for the last twenty years. Except when they play Philadelphia.

Washington University in St. Louis 